DOI: $10.17951 / \operatorname{lrp} .2019 .38 .2 .13-26$

\title{
ROBERT OPORA
}

Uniwersytet Gdański

ORCID: 0000-0002-1560-4136

\section{DIAGNOZA SYTUACJI PROBLEMOWEJ PODCZAS GRUPOWEJ TERAPII OSÓB NIEDOSTOSOWANYCH SPOŁECZNIE}

\begin{abstract}
Streszczenie: Celem artykułu jest zapoznanie czytelnika ze znaczeniem i sposobem przeprowadzania diagnozy w grupie terapeutycznej. Przedstawiona diagnoza sytuacji problemowej bazuje na założeniach koncepcji poznawczo-behawioralnej. W podejściu poznawczo-behawioralnym problemy osobiste są diagnozowane w kontekście specyficznych sytuacji, które sprawiają problem osobie lub jej otoczeniu. Funkcją diagnozy jest określanie zarówno ograniczeń podopiecznego, jak i jego zasobów. W tekście wskazane zostaną elementy składające się na pełen opis sytuacji problemowej. Precyzyjne opisanie sytuacji problemowej pozwala na poznanie sposobu spostrzegania problemowego zachowania przez podopiecznego i osoby z jego otoczenia oraz sprawia, że jest on możliwy do zmiany podczas terapii.
\end{abstract}

Słowa kluczowe: diagnoza, sytuacja problemowa, terapia grupowa

\section{WPROWADZENIE}

Większość współczesnych oddziaływań resocjalizacyjnych bazuje na koncepcji poznawczo-behawioralnej (Bartkowicz 2013; Urban 2000). Założenia tej koncepcji mogą być wykorzystywane zarówno w kontakcie indywidualnym, jak i w terapii grupowej.

Podstawowym celem artykułu jest przedstawienie adaptacji założeń koncepcji poznawczo-behawioralnej na potrzeby diagnozy sytuacji problemowej podczas terapii grupowej. Umożliwi to lepsze poznanie procesu kształtowania i osiągania indywidualnych celów psychokorekcyjnych podopiecznego.

Jedną z podstawowych form pracy z dziećmi i młodzieżą niedostosowaną społecznie jest terapia bazująca na interwencjach podejmowanych w grupie. Praca w grupie 
stanowi pewnego rodzaju kontekst, w którym stosuje się określone interwencje terapeutyczne z co najmniej dwiema niespokrewnionymi osobami w tym samym czasie.

Zgodnie z założeniami teorii poznawczo-behawioralnej, podstawą powstałych na jej bazie oddziaływań korekcyjnych jest założenie, że indywidualne przekonania wpływają na zachowanie danej osoby w określonej sytuacji (Opora 2010). Praktyczną implikacją takiego założenia jest dążenie do zmiany zarówno wzorców behawioralnych jak i treści poznawczych poprzedzających dane zachowanie. Celem interwencji poznawczo-behawioralnych podejmowanych wobec osób niedostosowanych społecznie jest uzyskanie wpływu na ich zachowania społeczne i towarzyszące im procesy poznawcze. Terapia poznawczo-behawioralna bazuje na możliwych do zweryfikowania doświadczalnie oddziaływaniach, nastawiona jest na kształtowanie społecznych i indywidualnych kompetencji, a także korygowanie zniekształceń poznawczych i likwidowanie deficytów.

Procesy poznawcze to obszerna kategoria struktur związanych ze sposobem w jaki człowiek spostrzega i koduje świat oraz doświadcza go. Osoby niedostosowane społecznie, zwłaszcza te cechujące się zachowaniami agresywnymi, wykazują zniekształcenia i niedobory różnych procesów poznawczych, które nie są jedynie odzwierciedleniem ich możliwości intelektualnych. Deficyty w procesach poznawczych, jak np. kłopoty z zaangażowaniem się w planowanie lub nieumiejętność radzenia sobie w trudnych sytuacjach zaobserwowano u dzieci i młodzieży z problemami samokontroli, takimi jak zespół deficytu uwagi z nadruchliwością oraz u dzieci z trudnościami interpersonalnymi (Kendall 1993). Dzieci agresywne dysponują ograniczonymi umiejętnościami konstruktywnego radzenia sobie w trudnych sytuacjach i rzadziej rozwiązują swoje problemy werbalnie (Lochman i in. 1991). W celu wyeliminowania deficytów poznawczych podejmowane oddziaływania psychokorekcyjne dążą do wykształcenia u dziecka nowych umiejętności poznawczych i behawioralnych. Większość programów i treningów poznawczo-behawioralnych uwzględnia więc uczenie umiejętności radzenia sobie w trudnych sytuacjach społecznych, poznawanie nowych strategii poznawczych, np. trening autoinstruktażowy, wewnętrzny monolog, ćwiczenie oraz samowzmacnianie, a także podnoszenie lub rozpraszanie uwagi. Wśród wspólnych elementów struktury programów poznawczo-behawioralnych znajdują się także oddziaływania takie jak psychoedukacja, zdobywanie nowych doświadczeń czy kształtowanie samokontroli, które mają za zadanie prowadzić do zastąpienia nieadekwatnych myśli bardziej prawidłowymi, wyważonymi i pozytywnymi aktami poznawczymi. Nowe umiejętności poznawcze i behawioralne podlegają wypróbowaniu, wyuczeniu, ocenie i wzmocnieniu. Wraz z poprawą funkcjonowania wychowanka, nowe umiejętności pozwalają mu radzić sobie z trudnymi sytuacjami w bardziej adekwatny sposób, dzięki czemu pojawiają się przyjemne uczucia, które wypierają nieprzyjemne. 
W przedstawionym tekście koncentruję się na znaczeniu diagnozy sytuacji problemowej, wybranych strategiach grupowych, które wspierają proces diagnozy, a także przedstawiam funkcje diagnozy. Na wstępie omówione zostaną cele diagnozy, które zwykle są osiągane w grupie terapeutycznej.

\section{CELE DIAGNOZY W TERAPII GRUPOWEJ OSÓB NIEDOSTOSOWANYCH SPOŁECZNIE}

Grupy terapeutyczne wykorzystujące koncepcję poznawczo-behawioralną są to małe grupy, których założeniem jest zachęcanie uczestników zajęć do osiągania indywidualnych celów. W pewnym stopniu różnią się one od grup psychoedukacyjnych, podczas których uczestnicy przede wszystkim uzyskują informacje o wybranych czynnikach ryzyka lub zjawiskach patologii społecznej, na przykład używania alkoholu w krótszej i dłuższej perspektywie.

Zanim zostaną podjęte oddziaływania korekcyjne, konieczne jest określenie natury przejawianych problemów i posiadanych zasobów do radzenia sobie z problemami przez podopiecznych. W podejściu poznawczo-behawioralnym osobiste problemy są oceniane w kontekście specyficznych sytuacji, które są odbierane jako problemowe (Kołakowski 2013). W sytuacji problemowej obserwujemy poznawcze, behawioralne i emocjonalne reakcje na nią, a także można dostrzec konsekwencje, jakie ponosi osoba w związku z tymi reakcjami (Siemionow 2016).

Określanie zasobów i ograniczeń w osiąganiu terapeutycznych celów jest również funkcją diagnozy (Cormier i Cormier 1991, s. 171-213). Można wyróżnić dwie grupy celów diagnozy. Pierwsza grupa celów odnosi się do zaplanowanego gromadzenia danych. Druga grupa celów dotyczy typów decyzji, jakie muszą być dokonane na podstawie zebranych informacji. Każda grupa celów zostanie osobno przedstawiona poniżej.

Celem gromadzenia danych jest:

1. Określenie, w jaki sposób spostrzegane jest problemowe zachowanie przez podopiecznego, jego rodziców lub inne znaczące osoby. Pomoc w takim sformułowaniu problemu, aby był on możliwy do zmiany podczas terapii.

2. Zidentyfikowanie sytuacji, które wywołują złość, agresję, stres i inne silne reakcje emocjonalne i niedostosowane zachowania szkodzące jednostce lub jej otoczeniu.

3. Określenie zakresu i intensywności nieadaptacyjnych i adaptacyjnych (lecz niewystarczających reakcji) i konsekwencji tych reakcji dla podopiecznego. 
4. Określenie u podopiecznego fizycznych, materialnych i psychologicznych zasobów przydatnych w terapii oraz rozpoznanie możliwych przeszkód w pomyślnej realizacji terapii.

5. Ustalenie wstępnej i późniejszej motywacji do zmiany.

Zgromadzenie niezbędnych danych diagnostycznych pozwala na podjęcie decyzji w zakresie:

1. Określenia optymalnych celów terapeutycznych.

2. Przygotowania planu w celu wdrożenia najbardziej efektywnych strategii korekcyjnych.

3. Określenia, czy terapia grupowa jest najlepszym miejscem do poradzenia sobie z problemem i podjęcia decyzji dotyczącej kwestii, w jakiej grupie dana osoba odniesie najwięcej korzyści.

4. Ustalenia, czy w kręgu podopiecznego pozostają osoby, które mogą być pomocne w procesie terapii.

5. Dokonania ewaluacji i udzielenia odpowiedzi na pytanie, na ile podjęta terapia jest skuteczna, dzięki porównaniu końcowej diagnozy z diagnozą początkową.

Chcąc osiągnąć powyższe cele, najczęściej wykorzystuje się dwie metody zbierania danych: wzajemne przeprowadzanie wywiadów przez uczestników grupy i terapeutę oraz dokonywanie systematycznych pomiarów. W tekście tym akcent położony będzie na wykorzystanie wywiadu grupowego i badań ilościowych na potrzeby uzyskania właściwej diagnozy i trenowania młodzieży w zakresie umiejętności przydatnych do określania celów terapeutycznych. $Z$ tego powodu na początku pracy z grupą terapeuta zwykle koncentruje się na nauczeniu uczestników zajęć prawidłowej komunikacji interpersonalnej. Istnieje szereg istotnych warunków skutecznej komunikacji w grupie. Na szczególne podkreślenie zasługują: poczucie komfortu uczestnika w kontakcie z terapeutą i pozostałymi osobami z grupy, motywacja uczestnika do otworzenia się przed grupą, umiejętności uczestników w zakresie prowadzenia wzajemnej rozmowy (Yalom, Leszcz 2006). W pierwszej fazie oddziaływań terapeuta musi pracować jednocześnie nad jakością wzajemnych relacji między osobami pozostającymi w grupie oraz zachęcać i wzmacniać stopniowe otwieranie się osób przed grupą, a także motywować do dokonywania zmiany. Jednocześnie grupa powinna rozpocząć proces definiowania problemowych sytuacji, podczas których zostaną ustanowione normy i uczestnicy zajęć nauczą się umiejętności prawidłowego rozmawiania. Chociaż diagnoza jest dominującą kwestią podczas wstępnego wywiadu i pierwszych spotkań grupowych (Yalom, Leszcz 2006), warto wspomnieć, że w praktyce trwa ona przez cały okres terapii. W momencie, gdy uczestnicy zaczną ufać sobie nawzajem, wówczas treści, jakimi się dzielą, stają się bardziej istotne i bogatsze w swej zawartości. Wstępne określenie 
odpowiedniej grupy dla każdej osoby, a później zdefiniowanie problemu, stanowią podstawowe zadania terapeuty. Kiedy cele i interwencje terapeutyczne zostaną określone, wówczas na bieżąco zbierane są nowe dane pozwalające na dokładniejsze dokonanie diagnozy podopiecznego. Ciągła diagnoza podopiecznego ułatwia podejmowanie decyzji dokonywanych podczas ewaluacji efektów końcowych.

\section{ANALIZA SYTUACJI PROBLEMOWEJ}

W tej części opisany zostanie sposób, w jaki analiza sytuacji problemowej przyczynia się do planowania oddziaływań psychokorekcyjnych.

Podczas zajęć osoby uczą się gromadzenia szczegółowych informacji dotyczących sytuacji problemowej i dostępnych zasobów oraz ich analizy. Również zwraca się uwagę na to, w jaki sposób rodzina i znaczące osoby mogą wspierać proces gromadzenia informacji. Podejście poznawczo-behawioralne różni się w pewnym stopniu od tradycyjnych paradygmatów terapeutycznych, które zazwyczaj akcentują diagnozowanie cech osobowości. W terapii poznawczo-behawioralnej uwaga koncentruje się przede wszystkim na opisie sytuacji problemowej i interakcjach uczestniczących w niej ludzi (Popiel, Pragłowska 2008). Sprzyja to szczegółowej analizie interakcji pomiędzy okolicznościami, przekonaniami i określonym zachowaniem (Mischel 1973, s. 265).

Podstawowe schematy reagowania na sytuacje są rozpoznawane poprzez sprawdzanie powtarzających się reakcji na sytuacje (Wolańczyk 2002; Sutton 2004). W poniższej części zostaną opisane poszczególne komponenty analizy sytuacji, tj. sytuacja - reakcja - konsekwencje oraz to, w jaki sposób uczestnicy zajęć ćwiczą w grupie przedstawiony schemat analizy. Na potrzeby szczegółowego wyjaśnienia każdy z elementów tego schematu jest opisany odrębnie.

\section{SYTUACJA PROBLEMOWA}

Sytuacja problemowa jest zbiorem zdarzeń stymulujących podopiecznego zarówno wewnętrznie jak i zewnętrznie. Zdarzenia te wywołują $u$ danej osoby reakcje stanowiące problem dla tej osoby lub jej otoczenia (Goldstein, Glick, Gibbs 2004).

W poniższym przykładzie osoba z grupy wypowiada się na temat własnego problemu. Sytuacja dotyczy ogólnego problemu.

Radek: Jestem nadpobudliwy i przez to wpadam w problemy (ogólny problem). Dzisiaj rano starsi chłopacy denerwowali mnie w szkole. Wyzywali mnie (sytuacja). Nie uderzyli mnie ani nic takiego. Nie pozwolę nikomu pogrywać sobie tak ze 
mną (reakcja poznawcza). Zacząłem ich wyzywać, sięgnąłem po krzesło i rzuciłem w nich (reakcja behawioralna). Oni uciekli (natychmiastowa konsekwencja). Dlatego dyrektor zatrzymał mnie (pośrednia konsekwencja). Było to trzecie tego typu moje zachowanie w tym tygodniu. Zostanę wyrzucony (konsekwencja długoterminowa), lecz to nie była moja wina. Oni nie powinni mi grozić (przekonanie).

W powyższym przykładzie uczestnik zajęć zidentyfikował pojawiającą się sytuacje, na którą reaguje dysfunkcyjną reakcją lub przekonaniem. Zazwyczaj tego rodzaju sytuacje problemowe osób niedostosowanych społecznie wiążą się $\mathrm{z}$ interakcjami z innymi ludźmi. Każda z sytuacji cechuje się tym, że sprawia problem jakiejś osobie lub wywołuje u danej osoby złość lub stres. Większość osób niedostosowanych społecznie zazwyczaj doświadcza natychmiastowych lub długoterminowych negatywnych konsekwencji. Celem oddziaływań może być pomoc tym osobom w zmodyfikowaniu ich dysfunkcyjnych reakcji na sytuacje, w zmianie dokonywanej przez nich oceny sytuacji lub unikaniu sytuacji (Ellis 1998). Żadna z tych strategii nie może być zastosowana bez prostego zdefiniowania komponentów sytuacji i reakcji uczestnika na nie. Można wyróżnić różne rodzaje sytuacji problemowych.

\section{INTERAKCYJNE SYTUACJE PROBLEMOWE}

Podczas zajęć terapeutycznych przydatna jest dyskusja z uczestnikami na temat sytuacji problemowych w celu udzielenia odpowiedzi na następujące pytanie: Kiedy pojawiła się ta sytuacja? Kto był zaangażowany? Co się stało podczas tej sytuacji? Gdzie miała ona miejsce? Jakie były specyficzne właściwości tego miejsca? Czy to zachowanie powtarzało się?

W myśl koncepcji poznawczo-behawioralnej podczas procesu diagnozy dodatkowo zadaje się dwa pytania: o czym myślałeś podczas tej sytuacji? Co czułeś wówczas? (Stallard 2006). Zazwyczaj odpowiedzi na te pytania wskazują na cele oraz metody oddziaływań terapeutycznych. Kiedy we wstępnych fazach oddziaływań poprosimy podopiecznych o opisanie problemu z jakim spotykają się w ostatnim czasie, wówczas rzadko odnoszą się do szczegółowych elementów danej interakcji. Podopieczni często prezentują sytuację w niejasny i złożony sposób. Po przedstawieniu problemowej sytuacji przez podopiecznego, terapeuta powinien zadać powyższe pytania, a następnie poprosić uczestników zajęć o odniesienie się do nich. 


\section{NIEINTERAKCYJNE SYTUACJE PROBLEMOWE}

Nie wszystkie sytuacje mają charakter interakcyjny, np. młodzież może mieć potrzebę wypicia alkoholu bez jakichkolwiek zewnętrznych i osobistych bodźców. Może dostrzec reklamę w telewizji, leżącą butelkę koło domu, czy też przypomnieć sobie, jak się czuł podczas ostatniego picia, może pomyśleć sobie o śmierci swojego brata bez wyraźnie określonej przyczyny, przez co stał się smutny. W większości przypadków nieinterakcyjnych sytuacji problemowych mamy do czynienia z bodźcami osobistymi lub poznawczymi.

\section{WSPÓLNE SYTUACJE PROBLEMOWE}

Niezależnie od tego, czy sytuacja ma charakter interaktywny czy też nie, większość grup rozpoznaje niektóre sytuacje jako wspólne dla kilku lub większości uczestników. W ten sposób dochodzi do pojawienia się efektu „witamy w klubie”, gdzie podopieczni dostrzegają, że inne osoby mają podobne do nich problemy (Opora 2010). Dostrzeżenie wspólnych sytuacji problemowych pozwala na zwiększenie efektywności procesu grupowego, ponieważ możliwe staje się jednoczesne modelowanie otwarcia się na grupę oraz wzajemne prezentowanie różnorodnych alternatywnych reakcji na te sytuacje (Yalom, Leszcz 2006). Ponadto terapeuci mogą również poświęcić więcej czasu osobom z grupy na pomoc w radzeniu sobie z prezentowanymi sytuacjami problemowymi, ponieważ są one ważne dla większości osób. Zaprezentowana przez jednego z podopiecznych sytuacja problemowa może być doświadczana i omawiana przez większość osób z grupy.

Sytuacje problemowe mogą odnosić się do bycia krytykowanym, poniżanym przez kolegów, rodzeństwo czy dorosłych. W większości przypadków wspólnymi reakcjami uczestników na trudne sytuacje są złość, agresja, grożenie, atakowanie, dysfunkcyjne myśli, chęć ucieczki (Urban 2012). Częstymi sytuacjami problemowymi związanymi z rówieśnikami czy członkami rodziny jest wywieranie nacisku w celu przymuszenia do podjęcia niedozwolonej aktywności, np. spożycia środków odurzających, włamania się do domu, uczestniczenia w niepożądanych sytuacjach.

\section{OPIS SYTUACJI PROBLEMOWEJ}

W celu zapoznania uczestników z analizą sytuacji problemowej, terapeuta wyjaśnia krótko pojęcie ogólnego problemu, sytuacji problemowej, reakcji i konsekwencji, a następnie obrazuje je za pomocą przykładów. Wskazuje on na związek mię- 
dzy problemem a konkretną sytuacją. Jeśli grupa ma charakter otwarty, wówczas terapeuta prosi starszych stażem uczestników, aby wyjaśnili pojęcia nowym uczestnikom i dostarczyli im przykładów z własnego doświadczenia. W grupach zamkniętych również można wykorzystać tę strategię. Bazuje ona na założeniu, że młodzież uczy się lepiej od siebie nawzajem (Tomkiewicz-Bętkowska, Czubak 2011). Jednocześnie jest to dodatkowe ćwiczenie, co zwiększa prawdopodobieństwo generalizacji trenowanych umiejętności.

Po zapoznaniu i zaprezentowaniu stosownych przykładów przez terapeutę i uczestników terapii, członkowie grupy są pytani o opisanie sytuacji jakiej doświadczyli, w której oni lub inni ludzie byli niezadowoleni z ich zachowania. Zwykle najlepiej najpierw poprosić o krótkie opisanie sytuacji i zapisanie jej na kartce podczas zajęć lub w ramach pracy domowej. Następnie uczestnicy prezentują te sytuacje pojedynczo $\mathrm{w}$ grupie lub partnerowi w parze, który podzieli się otrzymanymi informacjami z całą grupą.

\section{REAKCJE}

Adekwatność zachowania zależy od reakcji osoby na daną sytuację. Można wyróżnić trzy rodzaje reakcji: behawioralne, poznawcze i emocjonalne (Stallard 2006). Zazwyczaj pojawiają się one w zbliżonym czasie, lecz zostały rozdzielone poniżej na potrzeby analizy.

\section{REAKCJE BEHAWIORALNE}

Podobnie jak przy omawianiu problemowej sytuacji, większość adolescentów musi być uczona dokonywania szczegółowego opisu własnych behawioralnych reakcji. Kryteria pozwalające na dokonanie oceny poprawnego opisu zachowania przyjmują formę następujących pytań (Kołakowski 2013):

- czy reakcja jest obserwowalna?

- czy jest to reakcja na zaistniałą sytuację?

- czy reakcja ma określony wyraźnie początek i koniec?

- czy jest sformułowana jako działanie jakie ktoś przejawia zamiast tego, czego nie przejawia?

Pozytywna odpowiedź na każde z tych pytań prowadzi do dyskusji nad zachowaniem i otwiera podopiecznego na sugestie i późniejsze interwencje.

Odpowiednią dyskusję na temat behawioralnej reakcji można dostrzec w następującej wypowiedzi: Kiedy chłopiec powiedział „chwyciłem za krzesło i rzuciłem 
w nich" terapeuta i uczestnicy zajęć otrzymali pewien obraz behawioralnej reakcji. Jeśli chłopiec powiedziałby, że wycofał się, było by zasadne, zapytanie go o to, co powiedział w momencie, kiedy się wycofał. Należy zauważyć, że wszystkie te reakcje były sformułowane w kategoriach, co zostało zrobione, a nie: co zostało niezrobione lub niepowiedziane.

Istnieje wiele sposobów, w jakie młodzież może być uczona określania szczegółowych reakcji behawioralnych. Opisując zachowanie, warto pamiętać, aby zostało ono określone w jasny i precyzyjny sposób. Za zachowanie uznajemy wszystko to, co jest dynamicznym stanem widzianym bezpośrednio, np. chodzenie, sprzątanie, myślenie. Tak rozumianą reakcję można sprawdzić za pomocą tzw. testu trupa, tj. jeśli coś może zrobić trup, to nie może być zachowaniem, jeśli czegoś nie może zrobić trup, to jest to zachowanie (Kołakowski 2013). Dzięki znalezieniu odpowiedzi na pytanie, co robi dana osoba, a nie czego nie robi, można określić nasilenie zachowania, jego wpływ, miejsce i czas (Kołakowski 2013).

\section{REAKCJE POZNAWCZE}

W opisywanym tekście zakładam, że reakcja poznawcza jest to myśl, przekonanie, oczekiwanie, ocena, atrybucja czy autoinstrukcja możliwa do zidentyfikowania. Wiele z tych pojęć nakłada się na siebie. Przekonania mogą być dla danej osoby niejasne albo przejrzyste. Są one często wypowiadane głośno. Przekonanie może być prywatną czy ukrytą reakcją. Można je zazwyczaj zidentyfikować poprzez poproszenie osoby o opisanie przekonania lub zapisanie go i głośne przeczytanie lub poprzez dedukcję na podstawie zachowania lub stanu, w jakim pozostaje ta osoba.

W tym miejscu poświęcam szczególne zainteresowanie reakcjom poznawczym na sytuację lub powracającym myślom w związku z określoną sytuacją. Przekonania mogą również pojawiać się natychmiastowo przed sytuacją albo podczas jej trwania. We wcześniejszym przykładzie osoba odpowiedziała na zaczepki myślą: „nie pozwolę nikomu, aby w ten sposób pozwalał sobie wobec mojej osoby”.

Ze względu na osobiste doświadczenia, przekonania mogą być trudne do określenia, jednak wpływają one na definiowanie sytuacji oraz podejmowanie decyzji. Ważne jest rozpoznanie ich obecności jako reakcji na sytuacje problemowe i jednocześnie jako część sytuacji, która przyczynia się do dalszego rozwoju reakcji i sytuacji. Przekonania związane są z behawioralnymi i emocjonalnymi reakcjami (Beck 2005). 


\section{ROZPOZNAWANIE REAKCJI POZNAWCZYCH I EMOCJONALNYCH}

Większość osób niedostosowanych społecznie może mieć problemy z rozpoznawaniem swojego myślenia lub emocji jako reakcji na sytuację albo jako części sytuacji (Stallard 2006). Ćwiczenie rozpoznawania przekonań i wyrażania ich jest ważnym warunkiem wstępnym do poznawczej oceny sytuacji i dalszych oddziaływań korekcyjnych. W celu trenowania i weryfikacji przekonań terapeuta może przedstawić listę sytuacji wraz z generowanymi przez nie przekonaniami, aby wykorzystać je jako punkt wyjściowy do dalszej pracy.

Meichenbaum (1977) zasugerował szereg innych zadań, jakie mogą być wykorzystane podczas rozpoznawania przekonań młodzieży: symboliczne ćwiczenia, zadania, podczas których prowadzone są wewnętrzne dialogi na głos. Można również posłużyć się projekcyjnymi technikami prezentującymi na zdjęciach postacie $w$ interakcjach.

Podczas wyobrażania sobie sytuacji, młodzież odbiera swoje przekonania jako prawdziwe (Goldstein, Glick, Gibbs 2004). W ten sam sposób można rozpoznać mocne strony podopiecznych: analizując sytuacje, z którymi mają poradzić sobie w konstruktywny sposób. Ćwiczenie inspirowane wyobraźnią można wykorzystać do trenowania i modelowania umiejętności.

Na potrzeby rozpoznania reakcji poznawczych możliwe jest posługiwanie się zadaniami behawioralnymi. Podczas odgrywania ról, młodzież jest zaangażowana $\mathrm{w}$ poradzenie sobie z zachowaniem problemowym. Problemowe zachowanie może mieć zarówno miejsce w naturalnych warunkach, jak i w symulowanej sytuacji. Osoba zainteresowana poradzeniem sobie $\mathrm{z}$ tą sytuacją jest pytana podczas zdarzenia albo zaraz po nim o to, co mówiła do siebie podczas zdarzenia, albo jaka myśl jej przeleciała przez głowę, a także o doświadczane fizjologiczne reakcje, np. szybszą pracę serca, ściskanie żołądka, spocone dłonie, ból głowy, szybkie oddychanie (Popiel, Pragłowska 2008).

Innym sposobem uczenia rozpoznawania reakcji może być wykorzystanie zestawu obrazków przedstawiających problemy młodzieży podobne do problemów uczestników zajęć. Tak jak w metodzie studium przypadku, każda osoba lub grupa jest pytana o to, co dzieje się na obrazku. Młodzież jest również pytana o to, co te osoby z obrazka myślą i czują podczas interakcji. Wykorzystanie serii takich obrazków może pokazać, jak poszczególne osoby z grupy myślałyby w tej sytuacji i jak by się czuły.

Młodzież może sporadycznie identyfikować określone przekonania jako niedopasowane do ich sytuacji albo niejasne. Na przykład jeden z uczestników zajęć może stwierdzić, że we wszystkich sytuacjach trudno jest mu odpowiedzieć na pytania i stwierdzi: „myślę sobie, że nigdy tak się nie zachowam”. Taka sytuacja 
zazwyczaj może być rozwiązana przez zapytanie uczestnika o omówienie ostatniej sytuacji problemowej jakiej doświadczył, tj. miejsca i szczegółów sytuacji.

Odwoływanie się do analizy sytuacji zazwyczaj pozwala na rozpoznanie właściwości danej sytuacji, które poprzedzają lub pokrywają się z niepożądanymi reakcjami.

Inną techniką rozpoznawania przekonań w problemowych sytuacjach jest technika trzech kolumn opisana przez Becka i Emery (1985). W pierwszej kolumnie osoba opisuje sytuację powodującą pojawienie się nieprzyjemnej emocji, np. złości, w drugiej automatyczną myśl, w trzeciej zniekształcenia poznawcze.

Kolejną strategią wykorzystywaną do uczenia młodzieży rozpoznawania u siebie automatycznych (często autodestrukcyjnych) myśli i wiązanie ich z sytuacją w jakiej się one pojawiają jest schemat myśli (Wilkes i in. 1994, s. 146). Pierwsza kolumna jest wykorzystywana do opisania sytuacji, druga - do opisania emocji na skali intensywności od 1 do 10, a trzecia - do opisania myśli automatycznych.

\section{KRYTYCZNY MOMENT}

Krytyczny moment zachodzi w wyniku interakcji sytuacji z reakcją. Jest to punkt w sytuacji, który determinuje reakcję (Goldstein, Glick, Gibbs 2004). Olek opisuje ostatnie spotkanie w następujący sposób: „W momencie, gdy Jacek podskakiwał do mnie (krytyczny moment), ja go uderzyłem”. Krytyczny moment wywołał natychmiastową reakcję, w której Olek (z jego perspektywy) doświadczył nieprzyjemności ze strony Jacka, a następnie Olek uderzył Jacka.

Celem określenia krytycznego momentu jest wskazanie punktu poprzedzającego chwilę, w której podopieczny mógłby zrobić albo odczuć coś innego niż to, co w rzeczywistości zrobił (pomyślał lub poczuł). Wobec młodzieży można używać pojęcia trudny moment lub wyzwalacz czy zapalnik, zamiast krytyczny moment. Podczas skomplikowanych wydarzeń lub złożonych interakcji istnieje często wiele krytycznych momentów. Na przykład, kiedy Jola śpieszyła się, aby wyjść z domu na czas do szkoły, przewróciła pudełko śniadaniowe swojego brata (pierwszy krytyczny moment). Brat krzyknął na nią, a ona przybiegła do niego krzycząc. Mama powiedziała jej, aby zostawiła Piotra w spokoju (krytyczny moment). Jola krzyczała, że to była jego wina, ze złością trzasnęła drzwiami i wybiegła z domu. Mama zawołała ją z powrotem do domu i zaczęła upominać ją raz jeszcze (trzeci krytyczny moment). Na co Jola krzyknęła: nie wracam do domu. W grupie Jola mogłaby zostać zapytana o zidentyfikowanie krytycznych momentów, które jej dotyczyły. Grupa mogłaby pomóc jej znaleźć alternatywne reakcje na te krytyczne momenty. 
Terapeuta i podopieczni z grupy mogą dyskutować nad sytuacją, w której nie mają jednomyślnej opinii na temat tego, co jest momentem krytycznym. Natomiast osoba, której sytuacja jest omawiana, powinna być ostatecznym arbitrem swojego krytycznego momentu. Podczas ewaluacji różnorodnych alternatywnych reakcji młodzież będzie często przechodziła z jednego krytycznego momentu na inny.

\section{IDENTYFIKOWANIE NATYCHMIASTOWYCH I DŁUGOTERMINOWYCH KONSEKWENCJI}

Schemat sytuacja - reakcja - konsekwencja nabiera znaczenia i szczególnej wartości, gdy traktujemy go jako środek służący zmianie zachowania na podstawie krótkoterminowych i długoterminowych konsekwencji dla podopiecznego. Jeśli przejawiany wzorzec reagowania przez podopiecznego będzie się utrzymywał, wówczas analiza konsekwencji zachowania, zwłaszcza tych długoterminowych, pozwoli przewidzieć dalsze funkcjonowanie osoby w danej sytuacji (Sutton 2004).

Agresywne reagowanie w sytuacji przegrania podczas gry, przeklinanie, obwinianie innych za błędy, popychanie osób, które się obwinia, ma natychmiastowe konsekwencje w postaci utraty kontroli nad grą i długoterminowy rezultat w postaci odwrócenia się rówieśników i wejście z nimi w konflikt. Natychmiastowe konsekwencje mogą okazać się, jak w powyższym przypadku, wzmacniające, gdzie osoba obawiająca się odrzucenia ze strony rówieśników osiąga natychmiastowy efekt poprzez niestosowne zachowanie, przez co otrzymuje uwagę kolegów. Długoterminowym efektem będzie unikanie jej przez kolegów. Taki schemat jak sytuacja - reakcja - konsekwencja może stanowić konieczny przedmiot zmiany.

\section{PODSUMOWANIE}

Terapeuta, dokonując diagnozy podczas zajęć terapeutycznych, koncentruje się na gromadzeniu informacji na temat podopiecznych, gdyż dzięki temu możliwe staje się podejmowanie decyzji w zakresie dalszego postępowania z nimi. Także świadomość występowania różnych rodzajów sytuacji problemowych u podopiecznych pozwala terapeucie na właściwy dobór celów i metod terapii, a także odpowiednie pokierowanie procesem grupowym.

Według podejścia poznawczo-behawioralnego do zadań terapeuty należy uczenie podopiecznych prawidłowego rozpoznawania i opisywania sytuacji problemowych. Kiedy podopieczny lub jego rodzice dokonują opisów sytuacji lub formułują przekonania wyłącznie w uogólniony sposób, wówczas przy pomocy terapeuty i grupy 
uczy się ich przedstawiania treści problemowych w bardziej szczegółowy sposób. Nie da się uniknąć ogólnej dyskusji nad problemem. Jest ona punktem wyjścia do opisu konkretnych stwierdzeń odnoszących się do schematu sytuacja - reakcja - konsekwencja. Ogólny opis problemu powinien być również uwzględniony podczas zajęć, gdyż wyznacza on uogólnioną kategorię sytuacji i reakcji. Ogólne stwierdzenia stanowią więc punkt wyjścia do pracy nad szczegółowymi wydarzeniami. Przedstawiony w artykule szczegółowy sposób diagnozowania sytuacji problemowych pozwala na trafny dobór celów oddziaływania w zależności od potrzeb podopiecznego. Interakcyjna diagnoza sytuacji problemowej sprawia, że podopieczny rozumie swój problem i akceptuje go, dzięki czemu zwiększa się jego motywacja do pracy nad nim. Konkretny charakter diagnozy sprawia, że staje się ona mierzalna i pozwala na ewaluację podejmowanych oddziaływań terapeutycznych.

\section{LITERATURA}

Bartkowicz Z., 2013, Agresywność, kompetencje społeczne i samoocena resocjalizowanych nieletnich a ich przestępczość w okresie dorostości. Lublin, Wydawnictwo UMCS. Beck A.T., Emery G., 1985, Anxiety disorders and phobias. New York, Basic Books.

Beck J.S., 2005, Terapia poznawcza. Kraków, Wydawnictwo Uniwersytetu Jagiellońskiego. Cormier W.H., Cormier L.S., 1991, Interviewing strategies for helpers: Fundamental skills and cognitive behavioral interventions ( $3 \mathrm{rd}$ ed.). Monterey, CA, Brooks/Cole.

Ellis A., 1998, Terapia krótkoterminowa. Lepiej, głębiej, trwalej. Gdańsk, GWP.

Goldstein A.P., Glick B., Gibbs J.C. 2004, Program Zastępowania Agresji. Warszawa, Instytut „Amity”.

Kendall P.C., 1993, Cognitive-behavioral therapies with youth: Guiding theory, current status and emerging developments. „Journal of Consulting and Clinical Psychology", 61, s. 235-247.

Kołakowski A. (red.), 2013, Zaburzenia zachowania u dzieci. GWP. Gdańsk.

Lochman J.E., White K.J., Wayland K.K., 1991, Cognitive-behavioural assessment and treatment with aggressive children. W: P.C. Kendall (red.), Child and adolescent therapy: Cognitive-behavioral procedures. New York, Guildford Press, s. 25-65.

Meichenbaum D.H., 1977, Cognitive behavior modification: integrated approach. New York, Plenum.

Mischel W., 1973, Toward a cognitive social learning reconceptualization of personality. „Psychological Review”, 80, s. 252-283.

Opora R., 2010, Resocjalizacja: wychowanie i psychokorekcja nieletnich niedostosowanych społecznie. Oficyna Wydawnicza „Impuls”, Kraków. 
Popiel A., Pragłowska E., 2008, Psychoterapia poznawczo-behawioralna: teoria i praktyka. Wydawnictwo Paradygmat, Warszawa.

Siemionow J., 2016, Zmiana przekonań utrudniających adaptację społeczna u wychowanków Młodzieżowego Ośrodka Wychowawczego. Difin, Warszawa.

Stallard P., 2006, Czujesz tak, jak myślisz. Praktyczne zastosowania terapii poznawczobehawioralnej w pracy z dziećmi i młodzieżą. Poznań, Zysk i S-ka.

Sutton C., 2004, Psychologia dla pracowników socjalnych. Gdańsk, GWP.

Tomkiewicz-Bętkowska A., Czubak J., 2011, Zgrana klasa Ja Ty My. Impuls, Kraków.

Urban B., 2000, Zachowania dewiacyjne młodzieży. Kraków, Wydawnictwo Uniwersytetu Jagiellońskiego.

Urban B., 2012, Agresja młodzieży i odrzucenie rówieśnicze. PWN, Warszawa.

Wilkes T.C.R., Belsher G., Rush A.J., Frank E., 1994, Cognitive therapy for the present adolescents. New York, Guilford.

Wolańczyk T., 2002, Zaburzenia emocjonalne i behawioralne u dzieci i młodzieży szkolnej w Polsce. Warszawa, Akademia Medyczna.

Yalom I., Leszcz M., 2006, Terapia grupowa. Teoria i praktyka. Wydawnictwo Uniwersytetu Jagiellońskiego, Kraków.

\title{
DIAGNOSIS OF PROBLEMATIC SITUATION \\ IN THE GROUP THERAPY OF TROUBLED YOUTH
}

\begin{abstract}
The aim of the article is familiarizing the reader with meaning and method ot diagnosis in therapeutic group. Presented diagnosis of the problematic situation is based on assumptions of cognitive-behavioral concepts. In the cognitive-behavioral approach the problematic situation is individual problems are diagnosed in the context of specific situations, which are recognized as a problem by the person or the closest environment. The function of the diagnosis is the assessment of individual's barriers and strengths. There are elements significant for preparing the diagnosis of problematic situation. Precise description lets for understanding the way of perception problematic behavior by the person and environment and make it possible to change.
\end{abstract}

Keywords: essesment, rehabilitation, group therapy, trouble youth 